SJ Quinney College of Law, University of Utah

Utah Law Digital Commons

7-2021

State Complicity and Religious Extremism: Failing the Vulnerable Individual

Amos N. Guiora

Follow this and additional works at: https://dc.law.utah.edu/scholarship

Part of the Law and Society Commons, and the Religion Law Commons 


\section{State Complicity and Religious Extremism: Failing the Vulnerable Individual}

Professor Amos N. Guiora*

\section{Preface-May 2021.}

This contribution was originally written in 2019. These lines are written two years later, in May 2021

I have presented it at two different conferences, one in Israel, the other in Holland. Preparation for its publication in this distinguished collection required reading and deciding what, if anything, should be added or deleted. At the gracious invitation of Professor Cliteur, I am exercising the right to incorporate additional matter. However, before doing so, a word as to the piece's history and its incorporation in this project. In previous writings, I have examined the question of religious extremism, with a particular focus on the U.S., Israel, Turkey, the Netherlands, and the U.K; the analysis has, primarily, been through the lens of free speech and harm to members who live in a closed community.

A review of the other essay's included in this collection suggest an eclectic approach to profound contemporary issues that demand our attention. It is always interesting to see how different scholars, sitting in different areas of the world, examine challenging issues. From a reader's perspective the distinct questions raised, the different matters that concern each contributor, provide the reader with -----for lack of a better word----a compelling smorgasbord from which to sample, whether to their taste or not. In that sense, the hope is that the different essay's spark disagreement, discourse, and push-back for that is the essence of engaged give and take.

With that as our launching pad, a word regarding this essay: I teach at the SJ Quinney College of Law, University of Utah and live in Israel, outside Jerusalem. In addition, over the years I have spent significant time in the Netherlands, earning my PhD at the University of Leiden, under the sponsorship of Professor Cliteur. Living in Israel and Utah gives me a bird's eye view to religious extremism. As I try to explain in this essay, there are significant similarities between Orthodox Jewry and the Fundamental Latter-Day Saints. Though I am a self-described/defined secular Jew,

\footnotetext{
* Professor of Law, S.J. Quinney College of Law, University of Utah; this article greatly benefited from the research, editing, and contributions of Jessie Dyer, (JD expected 2020all SJ Quinney College of Law, University of Utah; Stacey Wright, J.D.; Tyler Hubbard (JD expected 2019), SJ Quinney College of Law, University of Utah, and Merrill (Max) Williams, (JD expected 2019), SJ Quinney College of Law, University of Utah; in addition, I am indebted to Professor Ross McPhail, SJ Quinney College of Law, University of Law, Coordinator, Quinney Fellow Program.
} 
living in Israel requires ----there is no choice---recognizing the reality of Orthodox Jewry and its complicated, and for me, troubled and troubling relationship with the State. My analysis of FLDS is more dispassionate because I am, obviously, not a member of the Latter-Day Saints (Mormons) Church and therefore do not have the same historical-personal-cultural connection Because I do not discern significant changes in the past two years regarding the FLDS Church, the following comments below will focus on events that have transpired in Israel in the past two years. My analysis of these events is, doubtlessly, impacted by my recent scholarship on institutional complicity and enabling cultures. While the application of those two themes has primarily focused on sexual assaults, the combination of complicity and enabling is highly relevant when examining religious extremism and the State.

I write these lines days after 45 Orthodox Jews, men and boys alike, were killed while attending a religious ceremony in northern Israel. They were trampled to death. While much ink has been spilled in Israeli since the event, and will continue to be spilled, one issue is of particular importance to us: the event reflects the absolute autonomy of Orthodox Jews in Israel and the total inability of state organs and national politicians to reign in the power of Orthodox rabbis and politicians. An Israeli politician who can say, "no" to the Orthodox community is, simply, not within the realm of the possible. This was evident during the COVID-19 crisis when Orthodox communities regularly disregarded all orders regarding social distancing and basic public health guidelines.

The thousands who attended funerals, who gathered at weddings, who sent their children to schools while secular and religiously observant Jews largely made the necessary adjustments in accordance with state issued guidelines. The thumbing of the nose, or more accurately, the collective middle finger went unpunished, devoid of any state sanctioned consequences. Truth be told, the extended closure period imposed on all Israelis was nothing more than collective punishment that would have not met any basic domestic or international law test. However, the inability of the Israeli government, dependent on the support of Orthodox parties in the ruling coalition, guaranteed two things: Orthodox who ignored state orders would not be held accountable and the secular community would be forced to pay the price as the government was unable to point a finger at the wrong-doing community.

In the context of this essay, it is the essence of state complicity. For secular Israelis this is a reality. The state, in reliance on my other research, enables this conduct. The resulting harm is extraordinary.

With that, I turn to the essay originally submitted for inclusion in this collection. 


\section{Introduction}

Religious extremism is harmful-a seemingly obvious statement; disagreement should be at a minimum. Daily news reports make that abundantly clear. Who is harmed and what are the factors responsible for that harm are the focus of this chapter? The assumption underlying the extremism-harm analysis is that there is a direct link between extremism and harm. In examining how to minimize the cost, and impact, of the harm this chapter examines the role, and obligation, of the state with respect to vulnerable members of society.

This chapter focuses on harm caused by religious extremists, and the harm caused by religious extremism to its members. That is to be distinguished from religion that practices tolerance of other faiths, has respect for different ways to exhibit faith and understands that not ascribing to any faith is legitimate and must be honored. Those qualities are not shared by those whose practice of their faith reflects intolerance, absolutism, and violence in the name of their particular faith. ${ }^{1}$

Religious extremism - especially when unhindered by the state - can result in unimaginable harm to individuals. That is not to suggest that the only extremism is religious extremism.

That would be patently incorrect and a profound misrepresentation of history; secular extremism - Communism, Fascism, Nazism, Pol Pot, Mao to name but the most obvious - has exacted an unimaginable price on hundreds of millions of people over the ages. While our examination will focus exclusively on religious extremism that is not intended - in any way - to minimize the extraordinary harm inflicted on innocent individuals by extremism not based on religion. To suggest otherwise would be an unacceptable combination of revisionist history, disrespectful of the memories of millions of victims. As we move forward, it is important to recall that in this chapter our focus is religious extremism and its impact on the individual. In doing so, we analyze the cost to the individual impacted by extremism and argue that state complicity in the face of extremism exacerbates individual vulnerability.

In focusing on individual vulnerability, the working assumption is that the state fails to protect the individual member of a closed religious extremist group. The obligation, and the consistent

\footnotetext{
${ }^{1}$ For a broader discussion of this issue please see, amongst others, Paul Cliteur, The Secular Outlook; Karen Armstrong, The Case for God: What Religion Really Means; Richard Dawkins: The God Delusion; Christopher Hutchins, God is Not Great.
} 
failure, to protect individuals in the face of religious extremism - particularly in the context of "closed communities" - has significant consequences. This chapter will focus specifically on the effect specific closed communities have on vulnerable individuals. Not only does it put individuals "at risk", it manifests state complicity in the face of extremism, the consequences of which are profound. While religious extremism is harmful to greater society, it is especially harmful to vulnerable individuals. With respect to the impact on larger society, specific examples will be provided illuminating the consequences of state complicity, regardless of its motivation or cause.

The state has a primary obligation to protect those who live within its borders and are subject to its rules, privileges, protections, and liberties. This is particularly acute for individuals who live within "closed communities"; however, as we shall come to see, it these individuals who are the most vulnerable on two distinct levels: they are "at risk" within their own community and largely unprotected by the state.

Rather than protecting vulnerable individuals from religious extremists, the state's inaction allows the religious extremist communities to continue in their way of life, thereby enhancing the vulnerability of "at risk" members of closed groups. In that sense, the state fails in its primary obligation. As we shall see in this chapter, that profound failure is not isolated to a particular country or a specific faith. At the core of the discussion is the question: to whom a duty is owed. This is at once a practical and philosophical question; the former from the perspective of the "at risk" individual; the latter from the perspective of the state's relationship with individuals and communities.

The protection afforded religious extremist communities can be understood as a shield: a shield protecting communities, enabling criminal actions against vulnerable members of those groups. In other words: rather than protecting individuals living within extremist closed groups, the state facilitates harm by shielding the group from larger society, including law enforcement, and tolerates the consequences of criminal activity.

That is the essence of complicity.

Part I is a definitional discussion regarding relevant terms; Part II examines religious extremism, past and present, and gives a brief overview of two groups: The Fundamentalist Church of Jesus Christ of Latter-Day Saints (FLDS) in the United States and the Ultra-Orthodox Jews in Israel. Additionally, Part II sheds light on the vulnerable individuals harmed by religious extremism and the failure of the state to protect them from harm. Part III addresses the impact of state complicity and how it multiplies ills of religious extremism. Subsequently, Part IV focuses on the state's duty to duty to protect vulnerable individuals who are harmed by religious extremism. 
Finally, Part $V$ suggests measures the state should employ to fulfill its duty to protect the vulnerable.

\section{Definitions}

Defining terms is essential to a discussion of this nature. The definitions offered below are necessary to address the issues in this chapter. There is no expectation they will be uniformly accepted; furthermore, it is safe to assume some terms will be found extraneous whereas other terms will be found missing. Reasonable minds can reasonably disagree. This disagreement is healthy; it facilitates debate and discussion. However, it is the hope that the need to define terms is met with near universal acceptance. ${ }^{2}$ That is not the same as agreement regarding preferred definitions. Failure to define terms - particularly in a discussion as fraught with complexity as this chapter undertakes-can easily result in unintended consequences, including government overreach. The primary reason definitions are important, is that it enables establishing parameters and contours regarding the issues discussed; because of the risks to individuals in closed communities and the risk to members of religious groups posed by government overreach, it is important narrowly - and concisely - articulate the limits of government intervention to an otherwise protected right.

There is great danger in casting too wide a net when discussing extremism by defining it too broadly. Failing to propose definitions similarly results in a discussion that is not grounded; that is a risky proposition when examining the triangle of religious extremism/tolerating intolerance/state complicity.

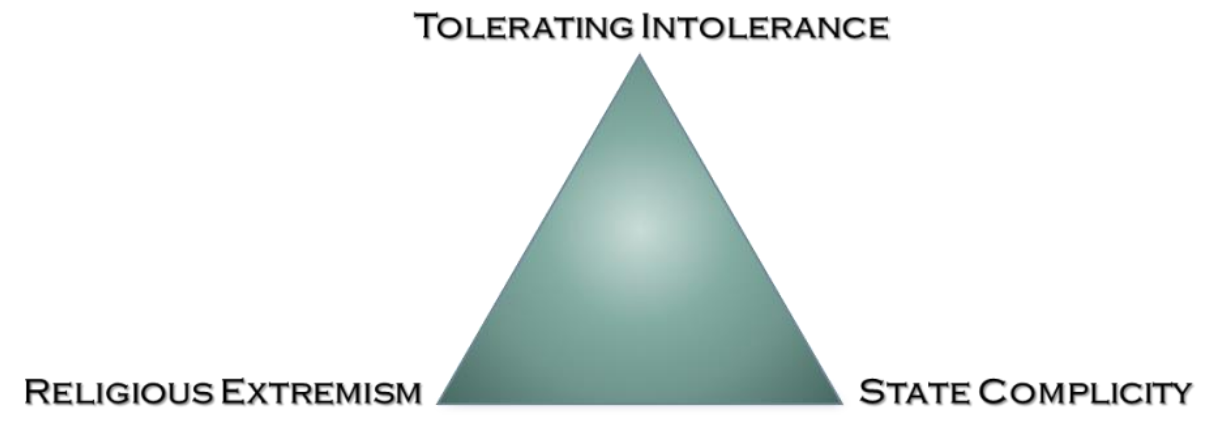

\footnotetext{
${ }^{2}$ In full confession: I am not convinced of the need to define religion; however, in response to comments received I decided to include a proposed definition that was largely suggested by The Dr. John C. Lentz, JR. with a slight modification on my part. I have, over the years, resisted defining the term but for the purposes of this article, offer the term included in the text.
} 
Devoid of definitions - whether there is consensus or not - the conversation is amorphous, lacking a baseline. More than that, if the discussion lacks definitions, it is but a short distance to an unwarranted limiting of otherwise guaranteed rights.

\begin{tabular}{|c|c|}
\hline Absolutism & A belief in the absolute rightness of one's beliefs. ${ }^{3}$ \\
\hline Bystander & One who stands by, ${ }^{4}$ knowing another is in distress and chooses not to act. \\
\hline Closed Groups & $\begin{array}{l}\text { Groups that espouse self-governance, self-discipline, reject external influence, and } \\
\text { in certain cases, reject government authority and legitimacy. }{ }^{5}\end{array}$ \\
\hline Complicity & Knowing there is a wrong and choosing not to intervene despite harm to another. ${ }^{6}$ \\
\hline Duty Owed & $\begin{array}{l}\text { Duty can be owed by the state to its citizens }{ }^{7} \text { or by individual } A \text { to individual } B \text { in } \\
\text { the context of particular relationship; }{ }^{8} \text { State duty is tempered by the adage, "you } \\
\text { can't put a policeman at every corner." }\end{array}$ \\
\hline Extremism & A willingness to impose harm on others in the name of a belief/ideology. ${ }^{9}$ \\
\hline Intol & $\begin{array}{l}\text { An unwillingness to be subjected to the opinions, beliefs, and perspectives of } \\
\text { others. }{ }^{10}\end{array}$ \\
\hline
\end{tabular}

3 See on this: Amos N. Guiora, 'Religious Extremism: A Fundamental Danger', 50 S, Texas Law Review, 2009 pp. 743 and 749 .

${ }^{4}$ See on this: Amos N. Guiora, The Crime of Complicity: The Bystander in the Holocaust, Ankerwycke Books, 2017.

${ }^{5}$ See on this: Amos N. Guiora, 'Protecting the Unprotected: Religious Extremism and Child Endangerment', Vol. 12, Journal of Law and Family Studies, 2010, pp. 391 and 398.

${ }^{6}$ Alexander F. Sarch, 'Condoning the Crime: The Elusive Mens Rea for Complicity', Vol. 47, Loyola University of Chicago Law Journal, 2015, pp. 131 and 140. "The simplest approach to identifying the mens rea for complicity is to take it that, in all cases, the putative accomplice must bear one of the criminal law's traditional mental states toward the underlying crime."

7 Steven J. Heyman, 'The First Duty of Government: Protection, Liberty and the Fourteenth Amendment', Vol. 41, Duke Law Journal, 1991, pp. 507 and 520.

${ }^{8}$ McCall C. Carter, Morality, 'Law and the Duty to Act: Creating a Common Law Duty to Act Modeled After the Responsibility to Protect Doctrine', 2, Washington University Jurisprudence Review, 2010, pp. 138, 141-142.

${ }_{9}^{9}$ Amos N. Guiora, 'Religious Extremism: A Fundamental Danger', 50 S, Texas Law Review, 2009, pp. 743 and 744.

${ }^{10}$ chronicle.com/article/The-Problem-With-Religious/233593. 
When defined positively-inclusion of multiple groups under the national/societal

Multiculturalism umbrella; ${ }^{11}$ when defined negatively-tolerance of harmful measures applied by closed groups to group members (e.g., honor killings). ${ }^{12}$

"Other"

Generally used by the mainstream when referring to ethnic or minority groups; the connotation is, generally, viewed negatively.

Religion

Certain beliefs held by a group of people about a higher power/s and a shared world view ${ }^{13}$

Religious A commitment to faith that includes the willingness to impose harm in the name extremism of the Divine. ${ }^{14}$

Religious violence Violence in the name of religious belief.

State complicity

When state agents and organs deliberately ignore a known and clear harm to vulnerable members of society ${ }^{15}$

Tolerance A respect for competing, alternate viewpoints other than one's own. ${ }^{16}$

Tolerating A rational-based decision to tolerate exclusion-if not harm-to members of intolerance

Vulnerable Members of closed communities deemed insufficiently devout (in closed religious members of communities), insufficiently modest in personal behavior, insufficiently respectful closed of the leader and requiring "re-education"; the harm emanates from communities governmental non-interference in the internal governance of a closed group. ${ }^{18}$

\footnotetext{
11 See on this: A. Stepan \& C. Taylor eds., Boundaries of Toleration, Columbia University Press, New York and Chicester, 2014.

12 Machteld Zee, Choosing Sharia: Multiculturalism, Islamic fundamentalism \& British Sharia Councils, Eleven, The Hague, 2015; Rumy Hasan, Multiculturalism: Some Inconvenient Truths, Politico's Publishing Ltd, 2010; Guiora, Amos, 'Multiculturalism and Religious Extremism: Whose Human Rights Do We Protect?', in: Gelijn Molier, Afshin Ellian, and David Suurland eds., Terrorism, Ideology, Law, and Policy, Republic of Letters Publishing, Dordrecht, 2011, pp. 337-361.

13 merriam-webster.com/dictionary/religion.

${ }^{14}$ Amos N. Guiora, 'Religious Extremism: A Fundamental Danger', 50 S, Texas Law Review, 2009, pp. 743 and 749.

15 chathamhouse.org/expert/comment/states-must-make-sure-cooperation-does-not-become-complicity.

${ }^{16}$ Amos N. Guiora, 'Religious Extremism: A Fundamental Danger', 50 S, Texas Law Review, 2009, pp. 743 and 748.

17 Id. "While civil democracy must allow for tolerance of religion, it cannot allow religious extremists to endanger society."

${ }^{18}$ See on this: Floris Van Den Berg, Philosophy for a better World, Prometheus Books, Amherst, New York, 2013.
} 
With these definitions in mind, we turn our attention to a discussion about religious extremism and state complicity.

\section{Religious Extremism}

\subsection{Religious Extremism: An Introduction}

From the perspective of religious extremists, extremism - or what broader society defines as extremism - is nothing more than zealous protection of their core beliefs and practices. The word zealous is not chosen randomly. After all, historically zealots were "members of a Jewish sect noted for its uncompromising opposition to pagan Rome and the polytheism it professed... Extremists among the Zealots turned to terrorism and assassination and became known as Sicarii (Greek sikarioi, 'dagger men.')." ${ }^{19}$ The zealous protection of an ideal, at the cost of harm to others, suggests extremism. Moderation, nuance, and gray areas are an anathema to an extremist; it is, for the extremist, an "all or nothing" paradigm intolerant of a less than total commitment to the ideal espoused by the group.

However, there are situations in which extremism is essential for physical survival. For example, soldiers - placed in situations of grave danger where moderation hastens death-will act in an extreme manner to survive. That may include subjecting themselves to physical hardship and unimaginable pain. For that, we congratulate them. Even though they were, in the moment, extremists. Similarly, the survivors of Death Marches in the Holocaust were subject to cruelty, horrific beatings, and terrible cold. Surviving required many things, among them the ability to withstand, and overcome, conditions that can only be defined "extreme". Surviving, then, required the ability to withstand extreme hardship; that is a laudable form of extremism.

However, that is not the extremism we are referring to. Rather, the subject of this chapter, is extremism that endangers others who do not share the belief system of the extremist, or do not draw the same consequences from it. That is, rather than individuals who can survive extraordinary hardship, using extreme measures, our focus is on individuals, or groups, whose commitment to their ideology, beliefs, and practices are extreme requiring absolute devotion, dedication and commitment that justifies, if necessary, harming others. It is the willingness to harm others that separates - distinguishes is another term - extremists from those who hold moderate beliefs and ideologies. In other words, it is the willingness to harm others - in the name of a belief system, religious or secular - that defines an extremist actor whose commitment to a particular cause justifies imposition of harm.

\footnotetext{
${ }^{19}$ Zealot, Encyclopedia Britannica. Available at.britannica.com/topic/Zealot (last visited Apr. 6, 2018).
} 
To illustrate the concrete harms that religious extremist groups can impose on vulnerable populations, below is background information regarding: (1) the Fundamentalist Church of Jesus Christ of Latter-Day Saints (FLDS); (2) the ultra-Orthodox community in Israel; and (3) other religious extremist groups. Similarities between these extremist groups converges upon a strict interpretation of religious tradition according to a premodern vision of life.

\subsection{The FLDS}

Much of what I know about the FLDS I learned when granted unlimited access, arranged by a third party, to a significant number of former members - men, women, and children - of the FLDS community. The conversations were extended, intimate, and painful, providing me with great insight into the inner workings of this religious extremist group. ${ }^{20}$ FLDS cannot be discussed without a brief mention of a separate and distinct church - The Church of Jesus Christ of Latter day Saints ("LDS Church" or "Latter-day Saints"). The LDS Church was organized in 1830 under the direction of Joseph Smith. ${ }^{21}$ In general, Latter-day Saints - often referred to as Mormons "believe that the marriage of one man is the Lord's standing law of marriage."22 Meaning, the institution of marriage is a focal point in the LDS Church doctrine. However, Latter-day Saints believe "the Lord commanded" Joseph Smith to institute the practice of plural marriage [the marriage of one man to more than one woman] among Church members in the early 1840s. For more than half a century, plural marriage was practiced by some Latter-day Saints under the direction of the Church President." 23

Eventually, the United States enacted legislation prohibiting polygamy, and the United States Supreme Court, in Reynolds v. United States, ${ }^{24}$ held that these laws were constitutional. ${ }^{25}$

In September 1890, Church President Wilford Woodruff... issue[d] the Manifesto... The Manifesto declared President Woodruff's intention to submit to the laws of the United States, and new plural marriages within [the U.S.] largely came to an end. ${ }^{26}$

\footnotetext{
${ }^{20}$ I never visited a FLDS community. An interested party suggested facilitating such a visit but then decided it was best for the visit not to take place. As was explained to me, the individual felt such a visit could, in his hands, "become unpleasant and get out of hand". To what extent he was correct is an open question, but I chose to accept his analysis. As a result, the only individuals with whom I met had left the Church (theologically and physically); I did not have an opportunity to see the community in person. This, no doubt, was unfortunate but I believe the extended conversations gave me significant insight.

${ }^{21}$ history.lds.org/timeline/tabular/chronology-of-church-history?lang=eng.

22 Ids.org/topics/plural-marriage-in-the-church-of-jesus-christ-of-latter-day-saints?lang=eng\#2 .

${ }^{23} \mathrm{Ids}$.org/topics/plural-marriage-in-the-church-of-jesus-christ-of-latter-day-saints?lang=eng\#2.

${ }^{24}$ Reynolds v. United States, 98 U.S. 145 (1878).

25 Reynolds v. United States, 98 U.S. 145, 152 (1878).

${ }^{26} \mathrm{Ids}$.org/topics/plural-marriage-in-the-church-of-jesus-christ-of-latter-day-saints?lang=eng\#2.
} 
In 1904, any members that participated in new plural marriage were to be punished by excommunication. ${ }^{27}$

Excommunicated members of the LDS Church came together and formed the FLDS, "forming a schism" between themselves and the LDS Church. ${ }^{28}$ The FLDS, which is currently composed of about 8,000 members, continues to practice polygamy today. ${ }^{29}$ For this reason, "[m]embers of the FLDS believe they are the true Latter-day Saints." ${ }^{30}$ As a byproduct of practicing polygamy, the FLDS condone the giving of "child brides" whereby underage girls are married to adult men with whom they engage in full sexual relations. ${ }^{31}$ Accordingly, what is otherwise understood to be statutory rape (sexual relations with a minor under the age of 16) or child abuse is an important tenet of FLDS members. ${ }^{32}$ We will return to the FLDS later in this chapter, examining it as a form of religious extremism, the state complicity enabling it, and, most importantly, the victims suffering from it. In addition, we will emphasize the extremist practices within the sect, specifically that it condones polygamy. Polygamy violates the principles of equality - mainly it dehumanizes the female individual.

\subsection{The Ultra-Orthodox Jews}

The ultra-Orthodox communities constitute 11.75 percent of Israel's population, numbering over one million at the end of 2017. It is important to recognize that referring to a monolithic "community" is incorrect; there are a number of separate communities, distinguished by different ethnicities, distinct interpretation of religious scripture, and allegiance to particular rabbis.

The ultra-Orthodox - also known as Haredi Jews - "practice the most conservative form of Orthodox Judaism." 33 The ultra-Orthodox segregate themselves from the secular world and have

\footnotetext{
${ }^{27}$ Ids.org/topics/plural-marriage-in-the-church-of-jesus-christ-of-latter-day-saints?lang=eng\#2.

28 The Primer, at 6.

${ }^{29}$ Michael J. Higdon, 'Polygamous Marriage, Monogamous Divorce', Vol. 67, Duke Law Journal, 2017, pp. 79, 94.

${ }^{30}$ Michael J. Higdon, 'Polygamous Marriage, Monogamous Divorce', Vol. 67, Duke Law Journal, 2017, pp. 79, 143.

${ }^{31}$ Amy Fry, 'Polygamy in America: How the Varying Legal Standards Fail to Protect Mothers and Children from Its Abuses', Vol. 54, Saint Louis University Law Journal, 2010, pp. 967, 973. ("The FLDS . . bond[] older men to child brides. ...").

32 Amy Fry, 'Polygamy in America: How the Varying Legal Standards Fail to Protect Mothers and Children from Its Abuses', Vol. 54, Saint Louis University Law Journal, 2010, pp. 967, 973. ("The FLDS sanctions this incest and child abuse, defending the practice as its constitutional right under the Free Exercise Clause.").

33 Jessica Nadler, 'The Struggle to Balance Religious Beliefs in a Modern Society: Conscription Options for Haredi Jews Post Ressler v. The Knesset', Vol. 20, Southwestern Journal of International Law, 2013, pp. 161, 163.
} 
little contact with the rest of Israeli society. ${ }^{34}$ "Most Haredi men dedicate their life to Torah study." 35 As discussed in greater detail below, the relationship between the ultra-Orthodox communities and the nascent State of Israel $^{36}$ was rooted in political calculations; in order to garner the support of the former for the creation of the latter, Israel's first Prime Minister David Ben-Gurion made a "deal" with the community's leadership: Haredi youth were to be exempt from service in the IDF in exchange for support for the establishment of the state. When the deal was struck in 1948, there were approximately $600 \mathrm{draft}$ age Haredi males in Israel. The reader will recall Israel has an obligatory military service; at present, women serve 24 months, men serve 32 months.

To what extent, Prime Minister Ben-Gurion fully understood and appreciated the long-term consequences of the arrangement is a matter of dispute amongst experts. What is clear, regardless of his intentions, is that an exception was created regarding the obligation to the state and its organs. This, at its core, defines the relationship between the Orthodox communities and the state and indirectly between the Orthodox community and the state's non-Orthodox population:

Most Israeli's will admit that the heart of the Haredi deferment debate lies in the policy's economic implications...

Since employment is prohibited under Torato Omunato, a Haredi man who chooses deferment often becomes reliant upon government support and subsidies. Some economists believe that the total value of the subsidies the Haredi population receives is as much as $\$ 750$ million, while the overall benefit if the community chose to work would be over $\$ 3$ billion to Israel's GDP. ${ }^{37}$

To that end, the ultra-Orthodox communities are not full participants in the state, do not have the same sense of responsibility to state organs and do not have a full bond to non-Orthodox communities, whether religious (but not Orthodox) or secular. This lack of full participation in the state, results in a closed community with vulnerable individuals. The harm that emanates from this distinction will be discussed further below.

\footnotetext{
34 Jessica Nadler, 'The Struggle to Balance Religious Beliefs in a Modern Society: Conscription Options for Haredi Jews Post Ressler v. The Knesset', Vol. 20, Southwestern Journal of International Law, 2013, pp. $161,163$.

35 Jessica Nadler, 'The Struggle to Balance Religious Beliefs in a Modern Society: Conscription Options for Haredi Jews Post Ressler v. The Knesset', Vol. 20, Southwestern Journal of International Law, 2013, pp. $161,163$.

${ }^{36}$ Established in 1948

37 Jessica Nadler, 'The Struggle to Balance Religious Beliefs in a Modern Society: Conscription Options for Haredi Jews Post Ressler v. The Knesset', Vol. 20, Southwestern Journal of International Law, 2013, p. 161.
} 


\subsection{The State's Failure to Protect Vulnerable Individuals}

Closed, religious extremist groups - such as the ultra-Orthodox in Israel or the Fundamental Church of Jesus Christ of Latter-day Saints (FLDS) in Utah - greatly benefit from state complicity in the face of their extremism. It enables the group to "function" in an isolated manner, free of state scrutiny, monitoring, and surveillance. The importance of this cannot be sufficiently stated when considering the harm caused by extremists to vulnerable members of their communities. These vulnerable members range from minors, women, or even individuals looking to leave the community.

The notion of complicity, in essence, means the state allows closed communities to practice selfgovernance, imposing rules, exacting punishments in accordance with the groups' particular beliefs and practices. The failure to engage closed groups, the deliberate decision to "turn a blind eye" to the inner workings of the group, reflects a failure to confront - and prevent - harm to individuals.

For the group, that is, frankly, most convenient. Enabling extremists to conduct their affairs in the dark shadows, away from mainstream society and its curiosity and thirst for knowledge, is a boon. When the state fails to protect vulnerable members of society against religious extremist groups, grave harm results. The harm is compounded should state agents choose not to intervene in the inner workings of the group. That is, not only is the individual at risk from group action but is also left unprotected by the state that makes a decision not to challenge internal workings of such groups. This is, frankly, nothing more than acquiescence with predictable consequences. The reasons are varied; none are particularly compelling nor convincing from the perspective of the "at risk" individual whose harm is compounded by state non-action.

From the perspective of the individual - the victim of state complicity - the consequences of State inaction are profound. They can be unimaginably painful, uncompromisingly brutal, and tragic.

\subsection{The FLDS in the Unites States}

The harm that religious extremism can impose on the vulnerable is readily seen when examining the FLDS. Much of the source of that harm is attributable to FLDS leaders, particularly Warren Jeffs who became the Prophet in 2002 after his father, Rulon, passed away. ${ }^{38}$ In 2007, Jeffs was convicted of accessory to rape in a Utah court; however, the conviction was subsequently overturned on a juror technicality. ${ }^{39}$ In 2011, Jeffs was convicted of sexual assault of a twelve-

\footnotetext{
38 biography.com/people/warren-jeffs-20771031.

39 biography.com/people/warren-jeffs-20771031.
} 
year-old girl and a fifteen-year-old girl, whom he had married. ${ }^{40}$ The Texas court sentenced Jeffs to life in prison. ${ }^{41}$ Upon Warren's incarceration his brother Lyle was to conduct Church affairs in his stead. However, in the aftermath of an indictment by a US District Court, Lyle went into hiding. In essence, Warren Jeffs continues to rule his flock from jail. ${ }^{42}$ While there are legitimate questions regarding the sustainability of the Church, it is clear Mr. Jeffs has the loyal support of many FLDS members.

Mr. Jeffs, prior to his incarceration, exercised total control over Church members. It is well-nigh impossible to understand the FLDS Church without recognizing the total control Jeffs had over members. That theme was repeatedly reinforced in my interactions. Were that not enough: the total control was emboldened, facilitated is another word, by the deliberate decision by state organs not to intervene in activities that were known broadly and were understood to endanger the welfare of group members. The combination of control and complicity are the linchpin in understanding the power of extremism and its consequences.

Those who had the temerity to disagree with him were punished. Punishment took many forms; my conversations with former members shed light on the following: banning from the community, shunning by the community, separation of families, forced re-marriage of wives whose husbands were punished, forced exile to remote locations, rape, and deprivation of food for children whose mothers angered their husbands. The FLDS also "abandons the boys who do not fully conform to the group, a move necessary in part to keep the numbers favorable to the men seeking multiple wives." ${ }^{43}$ This abandonment or shunning is extremely detrimental to a vulnerable individual in a closed community with little or no experience with mainstream society. While I heard rumors of significant physical harm (beatings), I was unable to corroborate these claims. Similarly, long standing rumors of murders were never substantiated. Nevertheless, there is no doubt Jeffs ruled with an iron fist. Those with whom I met never intimated there was a velvet glove, opposite of an iron first. It was, frankly, control through fear, power, and brute force.

Church members who dared to voice criticism were punished as outlined above. My interlocutors were uniform in stating Warren Jeffs exercised total control over their lives and of their families. In particular, they consistently noted Jeffs' sexual needs and the price young girls paid to meet them. One woman, with deep remorse and regret, was unable to explain how she consented to Jeffs' demand regarding her underage child. This woman, and others, emphasized Jeffs' status as

\footnotetext{
40 biography.com/people/warren-jeffs-20771031.

41 biography.com/people/warren-jeffs-20771031.

42 biography.com/people/warren-jeffs-20771031. ("Jeffs still controls the FLDS and its members from behind bars.").

43 Marci A. Hamilton, 'The Cognitive Dissonance of Religious Liberty Discourse: Statutory Rights Masquerading as Constitutional Mandates', Vol. 41, Harvard Journal of Law \& Public Policy, 2018, pp. 79, 83.
} 
the Prophet guaranteed him total obedience from members of the Church. The price for speaking up was harsh and unforgiving. This was absolute power, unchecked by the State that knew of these developments and their tragic consequences.

One commentator has aptly summarized the immense harm FLDS has on its members:

The belief system of an FLDS sect results in the men in polygamous families abusing the women and children that are a part of the sect and their family, among a host of other problems. Fundamentalist sects "foster incest, underage marriage, sexual abuse, rape, physical abuse, nonconsensual marriage, birth defects, welfare fraud, poverty, and a deprivation of education and other opportunities. ${ }^{44}$

\subsection{The Ultra-Orthodox Jews in the State of Israel}

Practices of the ultra-Orthodox communities result in many of its members suffering abuse, inequality, and isolation. Like the FLDS, the ultra-Orthodox communities are plagued by the evils of sexual abuse and domestic violence. Abusive men and fathers are, tragically, a part of culture. A casual reading of the daily news (in whatever form) brings this to light. ${ }^{45}$ One commentator has described wife abuse in Israeli Haredi society as "mostly hidden". ${ }^{46}$ However, there may be an explanation as to why that domestic violence is "hidden". In the article "Understanding Causes of and Response to Intimate Partner Violence in A Jewish Orthodox Community: Survivor's and Leaders' Perspectives" three barriers are addressed as to why Haredi women do not seek help or report instances regarding sexual violence. These three barriers are: (1) social values and attitudes; (2) fear of divorce and its aftermath; and (3) the evil tongue. ${ }^{47}$

Social values and attitudes are described as being especially powerful in the Jewish Orthodox community "because of its insularity and emphasis on family unity and harmony." When looking

\footnotetext{
${ }^{44}$ Amy Fry, 'Polygamy in America: How the Varying Legal Standards Fail to Protect Mothers and Children from Its Abuses', Vol. 54, Saint Louis University Law Journal, 2010, pp. 967, 973. This concept is furthered by Machteld Zee's research into Sharia Law, and the furthering of Islamization. In these places, "citizens do not have the right to challenge the Sharia rules that are placed upon them." Therefore, women, and other vulnerable individuals, can be seen as complicit due to an inability to challenge the system. Machteld Zee. Choosing Sharia: Multiculturalsim, Islamic Fundamentalism and British Sharia Councils, PhD Manuscript (1984).

45 washingtonpost.com/world/middle_east/in-israels-ultra-orthodox-community-abused-women-are-finding-away-out/2017/09/08/23ec4260-8115-11e7-9e7a-

20fa8d7a0db6_story.html?noredirect=on\&utm_term=.b1d2bc6816f8.

${ }^{46}$ Nicole Dehan and Zipi Levi, 'Spiritual Abuse: An Additional Dimension of Abuse Experienced by Abused Haredi (Ultraorthodox) Jewish Wives, Vol. 15, Iss. 11, Violence against women, 2009.

47 Shoshana Ringel and Rena Bina, 'Understanding Causes of and Responses to Intimate Violence in a Jewish Orthodox Community Survivors' and Leaders' Perspectives', Vol. 17, Iss. 2, Social Work Practice, 2007, pp. $281-282$.
} 
at eight survivors of sexual and physical abuse only two reported in this study stated that they found the Orthodox community supportive.

Survivors were also ashamed to admit that their marriage was unhappy because of the social value of family harmony, which mandated that families should preserve peace and harmony at any cost and 'not make waves.

Additionally, the strong emphasis on maintaining family privacy was seen as another barrier. When the article looked at leaders, four respondents indicated

domestic violence has always been a problem in the Orthodox community but has been covered up and hushed... hidden by the community and by women survivors because of shame and the fear of social stigma.

Fear of divorce and its aftermath seems to stem from the fear women have of losing custody and "jeopardizing their children's chances for a good marriage." When a survivor sought a divorce, she reported that "her fitness as a mother was questioned both by the community members and the rabbi." She stated that "women's fear of losing their children and possibly their community prevented them from leaving their husbands." A leader in the community reported that women are afraid to seek help because they are afraid that non-Orthodox counselors will encourage separation or divorce which are looked down on in the Orthodox community, but if they go to Orthodox counselors their family problems will become known in the community. The leader also stated that women are nervous about being a single mother, having to raise a family without adequate professional skills.

The last issue that was seen as a barrier was the evil tongue. This is described as "a powerful religious norm, stemming from the Ten Commandments, which require members to abstain from criticizing others or from speaking ill of them to others." Survivors reported that these things are not meant to be discussed "beyond the bedroom doors" and even if they were discussed "no one would listen, because both talking and listening is 'the same sin."' These three barriers reflect some of the reasons why physical and sexual abuse in Ultra-Orthodox communities go unreported.

Whereas in the past, abuse in the family was not discussed-society largely swept it under the proverbial rug - today the conversation is front and center. That is not to suggest all victims of abuse file complaints with local law enforcement or social services. It is, however, to note society has undergone a major shift on what was, once, a taboo topic. Without doubt, that is a most welcome change. 
However, unlike society as a whole, that does not extend to closed communities. That, perhaps, more than any aspect of the religious extremism-state complicity-tolerating intolerance triangle illuminates the consequences of deliberate inaction. The terms are chosen deliberately - knowing that women and children are at risk in Orthodox communities and yet failing to decisively act to protect them reflects a conscious decision. It is, frankly, unconscionable. However, it is important to note a tragic reality: Orthodox women, who are victims of abuse, are very hesitant to complain against their abusers. The reasons are varied.

They reflect a profound mistrust of state organs and paradoxical concern that complaining reflects trust in an entity (the state) that is inherently mis-trusted by Orthodox communities that live a life separate from state institutions. Some would argue there is a "Catch-22" that defines this very complicated relationship which, in many ways, is not a relationship. That nonrelationship relationship enables the abusers, while leaving the abused to fend for themselves. That is the essence of a vulnerable population. ${ }^{48}$

Apart from abuse and domestic violence, the practices of the ultra-Orthodox result in inequality between the Haredi men and women. In a study of textbooks used at Israeli schools, one research group found that women in those texts

are depicted as needing to undertake the perceived traditional male role of being responsible for a family's livelihood... Despite having the responsibility for wage-earning, Haredi women continue to be portrayed as traditional and modest, assuming the husband's role but remaining in the background. ${ }^{49}$

The depictions given in these textbooks at Haredi schools undoubtedly come to life in Haredi society. Not only do the women work while the men largely study religious scripture, but they are expected to have many children as well. Ultra-Orthodox women average 6.9 children (expected to drop to decline to 5.5 by 2025-2029), while their religious (non-Orthodox) counterparts average about 4 and secular Israeli's average 2.5. ${ }^{50}$

\footnotetext{
${ }^{48}$ washingtonpost.com/world/middle_east/in-israels-ultra-orthodox-community-abused-women-are-finding-away-out/2017/09/08/23ec4260-8115-11e7-9e7a-

20fa8d7a0db6_story.html?noredirect=on\&utm_term=.b1d2bc6816f8.

49 impact-se.org/wp-content/uploads/Haredi-Textbooks-in-Israel.pdf.

50 en.idi.org.il/media/4240/shnaton-e_8-9-16_web.pdf.
} 
As the graph below demonstrates, fertility rates among Haredi women have historically averaged around seven children. ${ }^{51}$ That is much higher than any other group based on group based on religious identification. One ex-ultra-Orthodox woman explained that her "womb was my family's measure of me." 52

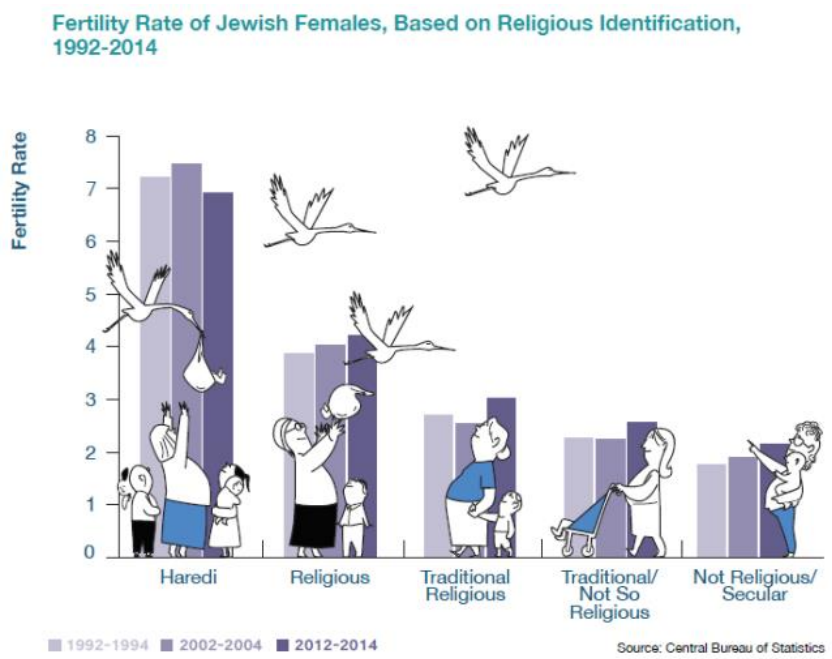

Source: en.idi.org.il/media/4240/shnaton-e_8-9-16_web.pdf

In many ways, ultra-Orthodox Jews - much like FLDS - are isolated from society. According to the Israel Democracy Institute, only 41 percent Ultra-Orthodox individuals over age 20 used the Internet in $2014 .{ }^{53}$ For context, 80 percent of non-Haredi Jews used the Internet in the same time frame. ${ }^{54}$ Only slightly more-54 percent-of the Haredim used a computer in 2014 , compared to 79 percent of the non-Haredi Jewish population. ${ }^{55}$ The ultra-Orthodox do not integrate socially with other Israelis. Indeed, 89 percent of the ultra-Orthodox claim that all or most of their close friends are also ultra-Orthodox. ${ }^{56}$

In addition to the harms the ultra-Orthodox impose on their own vulnerable members, they inflict substantial harm on society that is primarily borne by the majority. The beneficiaries are, primarily, the ultra-Orthodox who, in accordance with the decision by Prime Minister Ben-Gurion are excluded from mandatory Israel Defense Forces ("IDF") service. Over fifty years later, that deal remains essentially unchanged: all Israelis, by law-except for the ultra-Orthodox-have

\footnotetext{
51 en.idi.org.il/media/4240/shnaton-e_8-9-16_web.pdf.

52 vice.com/en_us/article/8gkygb/life-after-leaving-israels-ultra-orthodox-jewish-community.

53 en.idi.org.il/media/4240/shnaton-e_8-9-16_web.pdf.

54 Id.

$55 / d$.

${ }^{56}$ pewforum.org/2016/03/08/israels-religiously-divided-society/.
} 
obligatory military service. This obligatory military service-specifically the exception for the Ultra-Orthodox-is a topic of current discussion within the Israeli government.

While various efforts have been made to legislate the drafting of ultra-Orthodox males, political realities and considerations have dictated the preservation of the "status quo" enabling their continued exemption from the IDF. Over the years, different politicians, the Supreme Court, and a special committee have tried to find an equitable resolution to what is, at its core, inherently unfair. Best efforts notwithstanding, the continuing reality is that religious and secular Israelis bear a burden not borne by the overwhelming majority of the ultra-Orthodox community.

In years past, social stigma was attached to the Israelis who did not serve; that is no longer the case. For that reason, there is a decrease in the number of volunteers to combat units, an increase in exemption predicated on "unfit to serve" and a limited number of Conscientious Objectors. Nevertheless, the norm is that secular men and women serve; in addition, religious (not Orthodox) males also serve as do minority groups in Israel, including male Druze, Bedouin, Circassian, and Israeli Arabs. While a small number of ultra-Orthodox serve in a special unit, the price they pay is significant as they are shunned by their community, becoming outcasts.

On the most basic of levels, the "freeing" from military obligation of an entire population group is at the root cause of a profound sense of inequality regarding "sharing the burden," otherwise imposed by the state. ${ }^{57}$ Those who are not ultra-Orthodox are required to serve in the military and face all the accompanying risks of such service - time away from family, education, and work and, more importantly, possible injury or death. Meanwhile, the ultra-Orthodox do not confront these burdens.

Were that not enough, in accordance with Ben-Gurion's arrangement with Haredi leadership, Orthodox men have, over the years, not been gainfully employed in the work force. Rather, they spent their adult life in study of religious scripture with livelihood guaranteed by the state that because of a monthly stipend (salary). While this traditional model is changing because of its economic unviability; ultra-Orthodox men, particularly younger men, are increasingly entering the work force. In addition, in direct contrast to years past, ultra-Orthodox men and women are enrolling in institutions of higher learning. While this requires accommodations ---including separation of the sexes, demands regarding the gender of instructors --- there is no doubt this reflects an important change in the ultra-Orthodox communities.

\footnotetext{
57 aljazeera.com/news/middleeast/2014/03/qa-israel-ultra-orthodox-fight-enlistment2014313115953786681.html.
} 
That is in direct contrast to years past, when men spent their adult lives in study of religious text and Haredi women were part of the Israeli workforce:

Since employment is prohibited under Torato Omunato, a Haredi man who chooses deferment often becomes reliant upon government support and subsidies. Some economists believe that the total value of the subsidies the Haredi population receives is as much as $\$ 750$ million, while the overall benefit if the community chose to work would be over \$3 billion to Israel's GDP."58

Unsurprisingly, the ultra-Orthodox experience poverty at rates much higher than the rest of Israel. In 2013, 52 percent of ultra-Orthodox families lived below the poverty line compared to 12 percent of non-Haredi Jews. ${ }^{59}$ This poverty has resulted in less food security for the ultraOrthodox. While a substantial number of the Haredim do not work, those who do work earn smaller incomes on average than the rest of the population. Salaried ultra-Orthodox men earn only 7,577 NIS per month - the rest of the population averages 12,733 NIS per month.${ }^{60} \mathrm{~A}$ similar, although smaller, difference is present in the salaries of women. ${ }^{61}$ This difference is not surprising when considering the lower education levels of the Haredi. According to the Taub Center, 25.8 percent of the ultra-Orthodox experience residential crowing (live with more than two people per room). Only 2.1 percent of other Israelis experience residential crowding. ${ }^{62}$ Fewer Haredim own cars than other Israelis do: 37.7 percent compared to 74.4 percent. $^{63}$

\footnotetext{
58 Jessica Nadler, 'The Struggle to Balance Religious Beliefs in a Modern Society: Conscription Options for Haredi Jews Post Ressler v. The Knesset', Vol. 20, Southwestern Journal of International Law, 2013, pp. 161 (citations omitted).

59 The Israel Democracy Institute, Statistical Report on Ultra-Orthodox Society in Israel 17 (2016). Available at en.idi.org.il/publications/4282.

60 en.idi.org.il/media/4240/shnaton-e_8-9-16_web.pdf.

$61 / d$.

62 taubcenter.org.il/wp-

content/files_mf/therelationshipbetweensocialcapitalandhealthintheharedisectorenglish.pdf.

63 Id.
} 
Average Income from Salaried Employment, Individuals 25-64, Based on Population Group and Gender, 2014

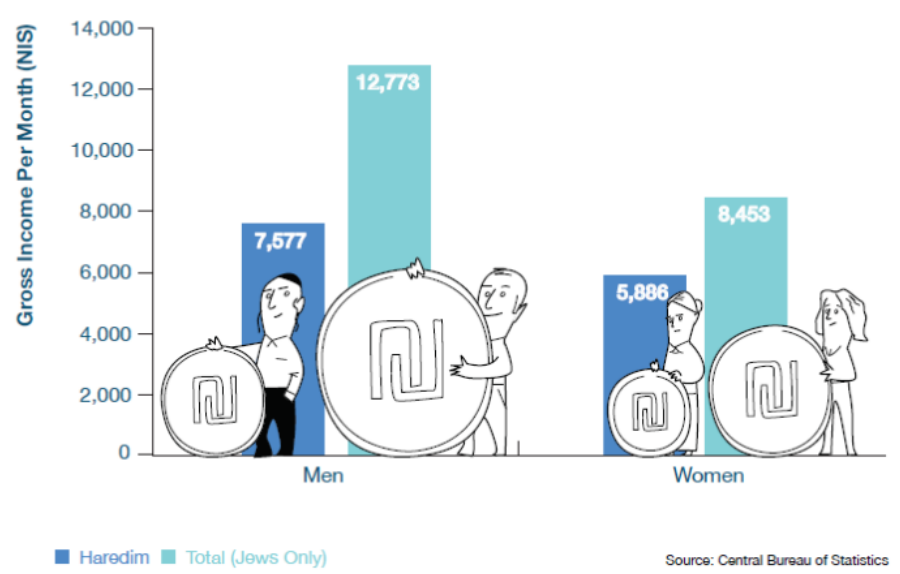

Source: https://en.idi.org.il/media/4240/shnaton-e_8-9-16_web.pdf

Figure 1

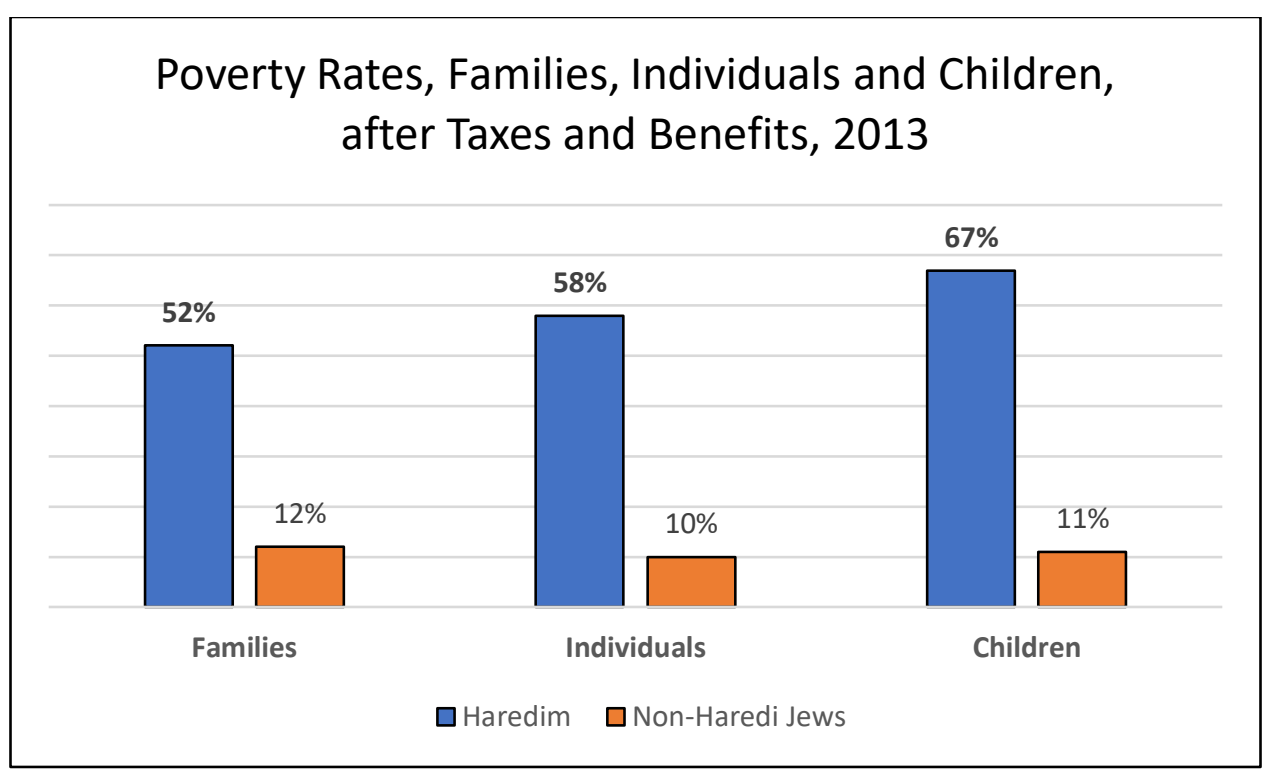

Source: en.idi.org.il/publications/4282. 


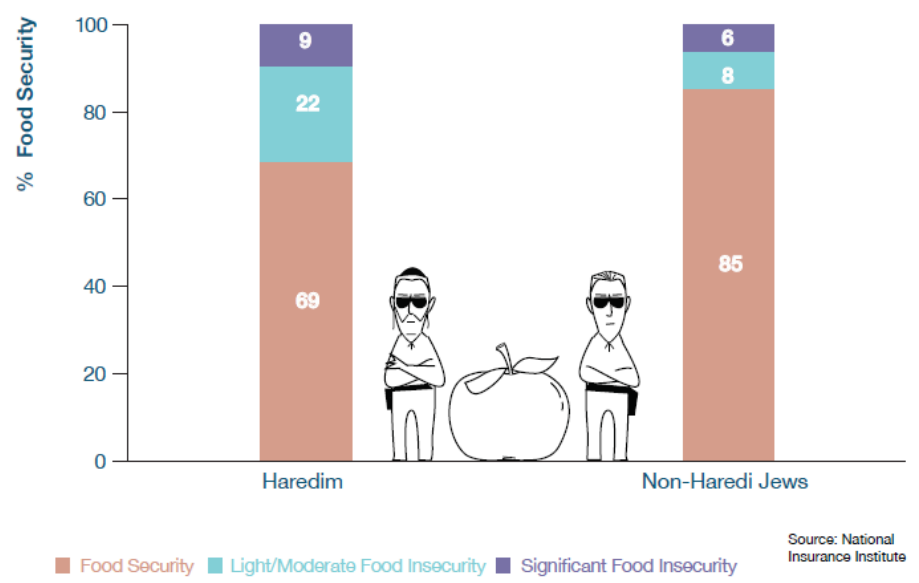

Source: https://en.idi.org.il/media/4240/shnaton-e_8-9-16_web.pdf

The cities in Israel with high populations of Ultra-Orthodox Jews are Jerusalem, Bnei Brak, Modi'in Illit, Beitar Illit, Beit Shemesh, Kiryat Ye'arim, Ashdod and El'ad. With the exception of Ashdod, each of these cities is in the top 25 percent of the poorest cities. Ashod is found in the top 50 percent of Israel's poorest cities, still relatively low.

\begin{tabular}{|l|l|}
\hline \multicolumn{1}{|c|}{ City } & \multicolumn{2}{|c|}{ Socio-Economic Ranking of Israel Communities, 1-255 (1 being the } \\
poorest)
\end{tabular}

\subsection{Other Religious Extremist Groups: Honor Killings - Kissing a cousin}

Religious extremism exists in many forms and throughout the world. In addition to FLDS and ultra-Orthodox, religious extremism is the essence of the Muslim practice of Honor Killings. Perhaps there is no more tragic, brutal, and primitive example of religious extremism than honor killings. It is, literally, all but impossible to fully grasp the horror and heinousness of killings in the name of "family honor". To be blunt: family honor is "code word" for the illicit, alleged or otherwise, sexual activity of a female member of the family; it is, with the reader's forbearance, honor as viewed through female genitalia. 
While serving as a Military Court Judge in the Gaza Strip (from 1993 to 1994) I was - until the case was correctly moved to a local, Palestinian court - the sitting judge in an Honor Killing case. While I had heard of Honor Killings, this was my initial, direct encounter with those responsible for committing an unimaginable crime. For the uninitiated, an Honor Killing is a deliberate decision - not "in the spur of the moment" - to kill a family member whose actions have tainted, dishonored, stained, the family's good name and reputation. In the overwhelming majority of the cases, the victim is a woman accused of sexual misconduct. Her actions have caused the family grave harm. To cleanse, or purify, the sole recourse before the family is to kill the individual responsible. As I came to learn, the cleansing requires a brutal, unimaginably painful death.

Before me, as defendants were three people: a mother and her two sons, in their early twenties. They had murdered their daughter - sister who they believed had kissed a cousin. For that offense, the family issued her death sentence; they were to be the executioner. The only way to truly understand the horror of Honor Killings is to come to grips with its sheer brutality. In that spirit: the young woman whose family ruled her death necessary was murdered over the course of an eight-hour struggle inside the family home.

The two brothers, acting in accordance with the mother's specific instructions, battered their sister who heroically resisted. She, according to their testimony, literally refused to die. When she was beyond exhaustion but still alive the mother ordered the sons to tie her to two separate beds (one leg to each bed) and then to "yank" the two beds as powerfully as possible in two different directions. The motion, which was powerful, literally split their sister in half. This caused her death.

What was remarkable was their demeanor in Court. There was no suggestion of remorse, no expression of regret, no emotion. The body language was stoic, signaling what was done had to be done. Meaning in the name of family honor, and what had stained it, the decision to kill the "stainer" was justified. The testimony made clear the brothers acted in accordance with the mother's instructions. In other words, they were foot soldiers; the mother was, literally, "judge, jury, executioner", with the brothers doing the actual execution. More than anything, sitting a few feet from them, I was struck by their calmness, almost serenity.

During the 18 months I served as a Judge in the Gaza Strip Military Court I heard the cases of Palestinian's accused of a wide range of terrorist activity. This was the only case that could be defined as criminal, rather than terrorist. Perhaps, for that reason it made a lasting impression on me. Or, perhaps, it was the sheer brutality of the action - including the unimaginably horrific and painful dénouement - that has caused me to often reflect on this case. 


\subsection{Other Religious Extremist Groups: Honor Killings - Modesty}

A newspaper headline from a number of years ago is telling: a Muslim father in Canada brutally murdered his teen-age daughter, in the family home, when she returned home past "curfew". In addition to being "late", the daughter's clothes-fashionably tight jeans and shirt-violated the father's understanding of modesty. ${ }^{64}$ In the home at the time of the murder, in addition to the father and victim, were the father's spouse and a second teen-aged daughter.

The mother claimed to have not heard her daughter screaming, pleading, and begging her father not to murder her. The father was unabashed in explaining his motivation: cleanse the family of the stain. In other words, his daughter had dishonored the family. Her death was inevitable. In the context of religious extremism - distinguished from moderate practice of faith - the father, from his perspective, was required to cleanse the stain. There was only one way to do so. Without doubt the act was horrific.

Compounding the terrible tragedy was a determination to minimize its root cause: the Toronto Globe and Mail presented the murder to its readers as a "domestic disturbance." It was not that. At all. The father brutally murdered his daughter in the name of religious extremism. This was nothing more-or less - than an honor killing similar in its brutality, heinousness, and motivation as the case before me in the Gaza Strip. To deny its true meaning, and what stands behind it, is both disrespectful to the victim and fails to directly address the horrors of violence predicated on religious extremism. That failure, both on a practical and philosophical level, reflects institutional complicity.

That is, in the name of tolerance, inherent intolerance is to be tolerated, even if the consequences are horrifically tragic. Important to recall: the tolerance of intolerance, at its core, enhances the vulnerability of at-risk members of closed societies. As was noted in the discussion above regarding FLDS, religious extremism - in the context of state complicity - are able to navigate their own waters, unrestrained by external monitors and checks. Granting religious extremists, the ability to engage in self-governance - be it FLDS, ultra-Orthodox, or Islamic extremists - has one profoundly important result: the abandoning of vulnerable members of closed groups.

The form of vulnerable takes many shapes; it is well-nigh impossible to suggest one particular model. However, there are consistent themes indicative of a recurring pattern: the vulnerability of women and girls because of religious extremism. That is not to suggest only religious

64 torontosun.com/2017/03/01/mississauga-dad-in-jail-for-daughters-honour-killing-dies/wcm/699285f2-9ba1480b-bfd4-f4f5095ed8cd. 
extremists violate women and girls, but it is to emphasize their vulnerability is exacerbated in closed communities predicated on religious extremism.

The extremism reflects separation between the group and larger society; the barrier between the two is, obviously, not cost-free. For group leaders-who are not vulnerable-the nonrelationship relationship is convenient for it gives them free reign regarding their relationship with group members. The notion of relationship is problematic; while the word suggests mutuality and interaction, in the context of the triangle we are addressing the word has a very different meaning.

It is a relationship in name only; in reality, the state fails to honor its obligation to the individual. In doing so, the state gives "cover" to the group, enabling it to conduct its affairs as it sees fit. The result, needless to say, is tragic: the group benefits from governmental non-interference; the state willfully turns a blind eye; the vulnerable individual is harmed. With no defensive shield.

\section{State Complicity}

The above examples demonstrate the harm that individuals suffer as a result of religious extremism. What is shocking is the state's role -through either action or inaction -in enabling that harm to occur. In this section we examine the role of state officials in (1) the United States (and especially Utah), and (2) Israel have had in facilitating the ills of religious extremism.

\subsection{The United States}

The harms caused by the FLDS have been perpetuated by the United States, and by the State of Utah. One commentator summarized possible reasons for state complicity succinctly:

Despite explicit prohibitions in state constitutions and inclusion in both state and federal statutes, officials [have] tolerated polygamous conduct. There are various reasons for this neglect. In some instances, government representatives feared that any "crackdown" on polygamists would be construed as a government attempt to abridge the constitutionally protected freedom of religion..... Further, enforcement has been ineffective because of the lack of police resources, societal prioritization of more significant or prevalent criminal violations, the inability to secure witnesses willing to testify against community spiritual leaders, and lastly, general misconceptions concerning polygamy laws. ${ }^{65}$

\footnotetext{
65 Jason D. Berkowitz, 'Beneath the Veil of Mormonism: Uncovering the Truth About Polygamy in the United States and Canada', Vol. 38, University of Miami Inter-American Law Review, 2007, pp. 615, 618.
} 
A key issue with the state complicity is the sensitivity of freedom of religion. Perception may be that religion receives a special protection-for fear of violating that freedom of religion-which ultimately condones harm to vulnerable individuals. This is done with that harm is perpetrated in the name of religion. As mentioned above, I learned about state complicity in regard to the FLDS when interviewing former members of the FLDS. My interviews with men, women, and children who had left the FLDS painted a painful picture of a terrible society ruled by Warren Jeffs and facilitated by the State of Utah's decision not to intervene on behalf of abused, violated, and harmed members. Reasons were proffered, excuses were made, spin was offered. None of it convincing.

In an "on the record" meeting the then Utah Attorney General, Mark Shurtleff, impressed upon me the difficulty of penetrating closed communities. The argument Attorney General Shurtleff made is best summarized as follows: "You need to understand, we [the state authorities] try, but the challenges are great." I found it then, and time has not changed my perspective, to reflect deliberate institutional ignorance of the travails of an "at risk" population group. It was wrong, it was dangerous, and it was unjustified. Mr. Shurtleff unapologetically explained state agents could not penetrate the closed community. When pressed, Mr. Shurtleff acknowledged harm was occurring while lamenting the operational difficulty of gathering sufficient evidence enabling criminal prosecution. In other words: the leading law enforcement official in the state was fully aware that crimes were committed in the state and yet sought to rationalize non-action predicated on operational challenges. The argument, in a nutshell, was that "yes, we know a crime is being committed, but no, there is nothing we can do about it".

Jeffs' evil and vile ways were enabled by the State of Utah. Simply put, for years, law enforcement, the judiciary, and state organs turned a blind eye to the reality of the FLDS. My interview with Attorney General Shurtleff, made it very clear that the State, while knowledgeable about the crimes committed by Jeffs and others, chose to ignore the harm visited on FLDS members. The reasons, as is to be expected, are complex and myriad. It is impossible to highlight or suggest one reason alone. What must be stated clearly is that the consequences were painful to hear.

That said, numerous conversations with thoughtful observers, who addressed the toxic combination of significant harm to vulnerable group members and the state's willful turning of a blind eye, suggested one recurring theme: the discomfort for state officials, many of whom are members of the LDS Church, to confront a group that originally splintered from the LDS Church. Additionally, 
[g]overnment officers in states such as Utah have expressed reluctance to target polygamists because of lasting memories of the persecution LDS polygamists received from the federal government, [and] finite law enforcement resources... ${ }^{66}$

Regardless of the reason, it is clear, and relevant for our purposes, that vulnerable members of the FLDS are left unprotected by the state. That is one of the tragic realities of a closed society: the group, under the leadership of one individual, or a small cadre, exercises total control, including assessment what punishment is to be meted out to way-ward members and then imposing that punishment free from external supervision and monitoring.

More than that, the practiced tenets, which violate state law, are tolerated and go largely unpunished by the state. In other words, the group's leadership exercises total control over the group, unfettered by the state, with individual will and decision-making subject to the whims of leadership. This is not an abstract matter, free of consequences for the individual. That, perhaps more than anything, was a powerful and painful refrain in my meetings. The individuals with whom I met - those who had left the faith-were consistent in articulating the ramifications of a closed group enhanced by state organs. Non-intervention left group members vulnerable to violence, sexual assault, and deprivation of human rights. It is the classic-and tragic-reality of a closed group free to do as it wishes with-and to-its members. The causes of this state complicity may be numerous. Most likely, however, it likely boils down to politics: "Children in the United States are routinely sacrificed on the pyre of their parents' faith by pandering politicians without a moral compass." ${ }^{67}$

\subsection{The State of Israel}

Similar to government officials in the United States, state actors in Israel have deliberately ignored the harms that the nation's ultra-Orthodox population have imposed on the vulnerable members of society. Specifically, the Israeli government is complicit with the ultra-Orthodox when they refuse to work, by subsidizing their schools, by exempting them from otherwise mandatory service in the IDF, and by turning a blind eye toward the many harms within their communities. ${ }^{68}$ By not intervening, the state-akin to the State of Utah-is forcing "at risk" population groups to fend for themselves in situations that are, largely untenable.

\footnotetext{
66 Jason D. Berkowitz, 'Beneath the Veil of Mormonism: Uncovering the Truth About Polygamy in the United States and Canada', Vol. 38, University of Miami Inter-American Law Review, 2007, pp. 615, 630.

67 verdict.justia.com/2015/09/17/the-plight-of-children-at-risk-in-the-ultra-orthodox-jewish-communities-and-thefailure-of-government-and-pandering-politicians-to-protect-them.

68 "There are many institutional barriers to stopping child abuse in the Haredi world. For example, there's widespread belief that reporting abuse to secular authorities constitutes heresy. Traditional religious law prohibits mesirah, or "handing over"-a Jew may not snitch on another Jew to a secular government." Available at
} 
In 2014, there were fourteen shelters that Israeli women victims of domestic violence could go to. ${ }^{69}$ That year, 755 women went to the shelter and sixty more "contacted the shelters for help... but didn't move in because there was no available space." ${ }^{70}$ The domestic violence issue is worst among the ultra-Orthodox. "Victims of domestic violence in the ultra-Orthodox communities face the unique obstacles of being from isolated communities that tend to be suspicious and lack relations with government services." ${ }^{71}$ Curiously, "Haredi schools ... do not permit Yad Sarah [an Israeli charity] to run seminars on domestic abuse for their students." 72 The Israeli government knows this.

Although, made in a different context, a quote by the founder of a Palestinian women's center in Israel describes the Israeli government's attitude toward ultra-Orthodox situation regarding domestic violence:

When I talk to police officers who say this is your culture, this is your identity, this is your tradition, I say no, this is not our tradition... This is violent men who want to control females around them, and they use this 'tradition' in order to make them feel good about what they are doing. And you [the police] are cooperating with them. ${ }^{73}$

The analogy is powerful and troubling, particularly from the perspective of the vulnerable members of society. By preferring to protect the institution of religious extremism, the state is complicit in harm to the individual.

Regardless of the explanation, or rationalization, the consequences are disturbing from the individual's perspective. The decision to tolerate extremism, in the name of political calculations and considerations, is the essence of state complicity in the face of harm. Important to note, the harm cuts across different sectors----while the primary focus is on members of the closed community, the decision to tolerate intolerance also impacts wider society. The most obvious example is Israel's secular population that bears the burden for what is best understood as the

newsweek.com/2016/03/11/child-abuse-allegations-hasidic-ultraorthodox-jewish-community-brooklyn432688.html.

${ }^{69}$ haaretz.com/israel-news/.premium-with-rise-in-domestic-violence-israeli-victims-search-for-solutions1.5403993.

${ }^{70}$ haaretz.com/israel-news/.premium-with-rise-in-domestic-violence-israeli-victims-search-for-solutions1.5403993.

${ }^{71}$ jpost.com/Israel-News/Police-highlight-domestic-violence-in-the-Orthodox-sector-476766.

$72 \mathrm{jta} .0 \mathrm{rg} / 2013 / 10 / 14 /$ life-religion/domestic-abuse-in-israeli-orthodox-community.

${ }^{73}$ middleeasteye.net/in-depth/features/double-standards-towards-domestic-violence-victims-israel-murderdiscrimination-women-Palestinian-222672937. 
"unequal burden", particularly regarding the high unemployment amongst male Orthodox Jews and the exemptions from IDF service.

One Israeli police spokesman described the ultra-Orthodox community as "difficult to penetrate." 74 The spokesman went on to say that "the police can get involved only when someone complains or provides information." 75 Unsurprisingly, "[o]ften, people do not complain." ${ }^{76}$ As a result, helpless women and children are often left to themselves to face their abusers. The Israeli government is also highly complicit in other ways. Because of coalition considerations - inherent to any parliamentary system - the main political parties (Likud, Yesh Atid, Labor in its various iterations) are dependent on small parties, including ultra-Orthodox parties, to create a government.

Forming a government requires 61 members of the Knesset (Parliament); current political realities are such that the largest party receives 25-35 seats in an election; to reach the "magical" number requires crafting a coalition including other parties. This gives enormous power and leverage to small parties that have very specific agendas serving their particular electorate. For the Orthodox parties, the single most important consideration in their coalition negotiations are a guarantee that the government will provide significant largesse to fund their school system.

Israel has three separate school systems, all state supported: public education $\mathrm{K}-12$ which provides a standard education (its quality is a separate discussion, unrelated to this project); national religious, for religious (not Orthodox) which combines religious with secular education; Orthodox (for boys and girls, but separate) whose curriculum (for boys) is exclusively focused on religious scripture (as previously noted).

The degree the state monitors the Orthodox school system is an open debate; it is understood amongst the broader public that the different factions ("Hatzer") within the Orthodox community exercise extraordinary discretion - unabated by external control-regarding how religious text is interpreted and taught. It is important to recall that the Orthodox (Haredi) community is not

\footnotetext{
${ }^{74}$ washingtonpost.com/world/middle_east/in-israels-ultra-orthodox-community-abused-women-are-finding-away-out/2017/09/08/23ec4260-8115-11e7-9e7a-

20fa8d7a0db6_story.html?noredirect=on\&utm_term=.09d2ab546259.

${ }^{75}$ washingtonpost.com/world/middle_east/in-israels-ultra-orthodox-community-abused-women-are-finding-away-out/2017/09/08/23ec4260-8115-11e7-9e7a-

20fa8d7a0db6_story.html?noredirect=on\&utm_term=.09d2ab546259.

${ }^{76}$ washingtonpost.com/world/middle_east/in-israels-ultra-orthodox-community-abused-women-are-finding-away-out/2017/09/08/23ec4260-8115-11e7-9e7a-

20fa8d7a0db6_story.html?noredirect=on\&utm_term=.09d2ab546259.
} 
unified; quite the opposite, for it is divided into distinct factions reflecting different historical and cultural backgrounds and influence, led by competing rabbis.

While secular Israelis may perceive the Orthodox camp as a monolith, presenting a common front of values, interests and beliefs, such a portrayal is inaccurate. Quite the opposite: the distinct camps have profound enmity regarding each other, sometimes marked by strong verbal vilification, if not physical violence. What unifies the Orthodox camps, or rather what distinguishes their commonality, is their disengagement from the state with one exception: their financial and political demands. The former emphasizes funding their separate educational system (as previously noted); the latter focuses on: a) deferment from the IDF; b) maintenance of the "status quo" regarding the Sabbath and religious affairs; c) non-intervention in internal communal affairs; and d) continued state subsidization of their particular culture.

The consequences of these demands, to which the state largely accedes, is that a community (actually, sub-communities) is allowed to exist within the state while divorced from mainstream society yet financially supported by that state. This is, needless to say, an anomaly: citizens of the state, whose way of life is dictated by religious beliefs that, for them, justify non-involvement in all matters related not directly related to theirs. That anomaly is, from the perspective of those not members of the closed group problematic, to say the least.

The problematic-ness focuses, in particular, on three distinct aspects of this unique-if not ununderstandable-arrangement: exemption from IDF service; lack of contribution to the national economy (the result of not working); imposition of Sabbath related "rules", two in particular: the closing of businesses thereby limiting when secular Israelis can shop and the closing of particular roads. The former is particularly inconvenient; because of the extended hours many stores are closed on for the Sabbath, beginning Friday afternoon through Saturday night (the Israeli work week is Sunday-Friday). Road closings do not-in the main-impact secular Israelis, though the issue is "used" as a test of political strength, particularly, but not exclusively, in Jerusalem.

There are, naturally, consequences to this arrangement. Tolerating the setting off of one community from the larger community is not cost-free. Not in the least. To truly understand the consequences of this arrangement requires recognizing the harm inherent to tolerating a closed community within a state. The costs on society have been addressed above, ranging from inequality in "sharing the burden", to significant disparities in education and employment between the secular and religious communities and the ultra-Orthodox, to the limits imposed on a secular lifestyle, whether regarding shopping or driving. These reflect political realities; they also reflect costs borne by society at large. 


\section{The State's Duty: To Whom is it owed?}

Now that we have seen how religious extremism can harm vulnerable individuals, the question must be asked: To whom does the state owe a duty? This is one of the most important questions governments face. It is not a new question. It is, however, a largely unresolved question... Perhaps that is surprising given how much attention, over the years, the question has been drawn. It has been the focus of endless debate, articles, books, and public discussion.

The question is of extraordinary relevance when considering "at risk" communities. However, it also relevant for working men and women, living their lives in accordance with the rule of law, subject to majoritarian rule, guaranteed the privilege of holding minority viewpoints, and relying on government protection. That is, the question is relevant both for those who choose to live outside mainstream society and for those who live their lives within the context of mainstream society. Tragically, governments' articulation of duty owed to those living in closed societies is far murkier, if not darker, than for the rest of society.

That differentiation, perhaps reflecting convenience-an unwillingness to confront closed groups, particularly but not exclusively religious extremists-endangers vulnerable members of the closed group. The concern regarding vulnerable members is acute for, as we will come to repeatedly see, their endangerment is enhanced when group leaders understand government is unconscionably hesitant to intervene. That disturbing theme is at the core of this chapter.

The broader question regarding duty owed is unresolved for a variety of reasons, perhaps primarily because decision makers, the public, the courts, law enforcement, pundits, and others cannot consistently agree on the relationship between the individual and the state. Resolving the "duty owed" question, as complicated as it is, depends on how the relationship between individual and state is defined. That is far easier said than done. After all, even the meaning of the word "individual" is unclear; much less to whom does a state duty extend. Is the duty owed to these different categories similar or are gradations and nuance tolerated?

Does it refer to citizens, residents, legal aliens, illegal immigrants, migrants, refugees, tourists, amnesty seekers, people in transit, and any other possible iteration of someone in a particular country at a moment of crisis? The migrant-immigrant crisis of the past years has brought to light, in a stark manner, this poignant and complicated question. It is reminiscent of previous humanitarian crises, in which the individual's status was critical in determining whether government owed a duty and if yes, to what extent. 
History is replete with such examples in which the duty owed question is either unsatisfactorily resolved or, equally ominous, left to local officials to decide the fate of those unfortunate enough to be in their midst in time of conflict. Those, however, are instances best defined as nonnormative. They, in the ideal, differ from normative circumstances when government is fully functioning, in control of its borders. In other words, we are posing the duty question in the context of a fully functioning government, in control of its resources and priorities unencumbered by external influences and burdens.

That makes the failure to protect far more troublesome; perhaps we can tolerate - or at least understand - the failure to protect a particular population group when government is under attack and resources are extraordinarily limited and conditions fraught with immediate danger. In other words, in a "life and death" situation - for instance, war - the determination of which population group warrants protection is fundamentally different than in time of peace. That is not to excuse failure to protect when rockets are being fired but it, in the same vein, to note that exceptional times must be recognized and their complexity not under-estimated.

In answering these questions, it is essential to recognize the issue of "cost"; extending less than full protection enhances vulnerability, particularly to those whose positions are invariably weak. Vulnerability is both physical and emotional: for migrants, vulnerability in the face of attack from right-wing nationalists is well-documented; for women and girls believed to have stained family honor, the consequences are clear. That is, we must keep in mind that the failure to protect can result in unimaginable tragedy. The cost is real and visceral.

Both population groups - as but examples - are in harm's way. That is obvious from a casual perusal of the daily news. They are not the only population groups under attack - racial and ethnic minorities, even when lawful residents of a country, are also targets. That, too, is obvious from a daily news digest. The distinct categories - migrants, women belonging to a closed society, nationals who are minorities - are all deserving protection. A duty is owed to them by the government. While our focus is the vulnerable members of a closed group, important to recall other members of society are also vulnerable. In focusing on members of closed groups, we are not ignoring danger posed to members of society who do not belong to a closed group.

In summation, the state has a duty to protect all vulnerable members of society - both vulnerable members of the extremist group and vulnerable members not of the group - not religious extremist groups. The state must recommit itself to this duty.

\section{Protecting the Vulnerable: The Way Forward}


The important question to answer is: will state organs answer the call of duty by taking necessary steps to protect vulnerable members closed extremist groups and other members of society that are defenseless against extremist groups? Obviously, it is impossible to protect all the people, all the time. We expect the state to protect us from harm. We expect state agents will act in our best interests in an effort to ensure our safety. In return, the body polity endeavors to be lawabiding, respect state organs, and respect the rights of other members of the body polity.

There is a two-fold quid pro quo, one between the individual and the state; the second, between individuals. Both (state-individual and individual-individual) reflect mutual self-interest - selfpreservation, mutual protection, and confidence in banding together. The concept of banding together - what Stephen Ambrose defined in his iconic book, "Band of Brothers" - is an accurate description of the Social Contract.

While there is, obviously, a difference between members of society and members of a military unit, there are similarities relevant for our purposes. In both cases, there is mutuality of purpose and cause; soldiers for all the obvious reasons, society because of the fundamental human desire for protection. That does not imply consensus on issues and dilemmas confronting the body polity; it does, however, imply the centrality of desiring protection, security, and safety. That, however, does not automatically translate - even in the best of circumstances - to full protection. The Social Contract is a coming together, not necessarily predicated on friendship and comity, but more reflective of an agreement, or arrangement. On the premise this is willingly entered into, with boundaries, obligations, and duties clearly delineated, the Social Contract - from a contractual perspective - is fulfilled. On the face of it, the relationship is clear and uncomplicated: we (the people) voluntarily relinquish certain rights, privileges, and liberties; in return you (the government) protect us; from the government's perspective the arrangement is best articulated as, "We protect you, in return you join the polity and live in accordance with our rules, regulations, and laws." Simple enough.

Now, more than ever, the state must reassess the interpretation of the Social Contract that it currently employs regarding religious extremism and the protection of individuals. It must reevaluate its duty to protect the helpless from extremist groups. Doing so will not be easy. As noted in the previous section, politics is a major hindrance to the state carrying out its duty. And that obstacle will not easily be overcome. Even so, we must strive to conquer it. If the state does not protect the vulnerable, nobody will. This is especially true as to vulnerable children:

When a faith community follows a path that endangers children, those children have few if any defenses. Only other adults can help them. When their faith-filled parents can or will not protect them, ... they become the responsibility of the government and 
elected officials. When the government and vote-pandering politicians turn the other way, these children suffer. ${ }^{77}$

We now briefly mention three possible steps society and the state could take to better protect helpless individuals.

First, the state must prosecute the crimes perpetuated in religious extremist groups such as sexual abuse, domestic violence, polygamy and fraud. This sentiment was echoed by one commentator who highlighted a powerful sentence from the Utah Supreme Court: "However free the exercise of religion may be, it must be subordinate to the criminal laws of the country." 78 We cannot allow religious extremists fearing prosecution, "to retreat to closed enclaves, where abusers benefit from their victims' isolation." 79 Instead of waiting for complaints-which will likely never come-law enforcement should be more proactive in protecting the vulnerable.

Second the state must help vulnerable members of extremist groups providing them access to shelters. Many individuals leave extremist groups, hoping to find a new role in society. But that is no easy task. For example, "[l]eaving the ultra-orthodox world involves tremendous challenges, as those who leave are cut off by their families and communities, and do not have the education needed to get jobs." 80 The same problem arises in the ex-FLDS population: "With little to no education, job skills, or social skills, the women who mothered sometimes dozens of children had to learn to fend for themselves-some bearing the burden of caring for their children alone or facing reality while being exiled from their families and the only community they've ever known." 81 In Israel, there are "only two shelters . . . dedicated to Orthodox and ultra-Orthodox Jewish women." 82 This is despite the "increase in the number of Haredim women seeking help in recent years." 83

\footnotetext{
77 justia.com/2015/09/17/the-plight-of-children-at-risk-in-the-ultra-orthodox-jewish-communities-and-the-failureof-government-and-pandering-politicians-to-protect-them.

78 Amy Fry, 'Polygamy in America: How the Varying Legal Standards Fail to Protect Mothers and Children from Its Abuses', Vol. 54, Saint Louis University Law Journal, 2010, pp. 967, 970. 967,

79 Sarah Rogozen, Prioritizing Diversity and Autonomy in the Polygamy Legalization Debate, 24, UCLA Woman's Law Journal, 2017, pp. 107, 143.

80 hillel.org.il/en/about.

${ }^{81}$ thespectrum.com/story/news/2017/04/21/flds-women-forgotten-healing-inside-out/100700534/

82 washingtonpost.com/world/middle_east/in-israels-ultra-orthodox-community-abused-women-are-finding-away-out/2017/09/08/23ec4260-8115-11e7-9e7a-

20fa8d7a0db6_story.html?noredirect=on\&utm_term=.09d2ab546259.

${ }^{83}$ washingtonpost.com/world/middle_east/in-israels-ultra-orthodox-community-abused-women-are-finding-away-out/2017/09/08/23ec4260-8115-11e7-9e7a-

20fa8d7a0db6_story.html?noredirect=on\&utm_term=.09d2ab546259.
} 
One of those shelters is Hillel, which is "dedicated to helping former ultra-Orthodox Jews, and as such provides them with a full set of services including psychological counseling, housing, educational scholarships, vocational help, and mentorship." ${ }^{84}$ Bat Melech is the other organization that "runs a network of shelters and safe havens that provide social, financial, emotional, and legal assistance to" abused Orthodox and Ultra-Orthodox women. ${ }^{85}$ Similarly, Creekers Foundation is a "group offering support from the inside" 86 to recovering ex-FLDS members. This is important because "ex-FLDS are plagued with suicide, drug addiction or ... [have] been completely ostracized from their relatives." 87

Knowing that the ultra-Orthodox and the FLDS "distrust non-religious authorities," 88 the state should employ the tactic of funding more organizations such as Bat Melech and Creekers Foundation. As of 2017, Bat Melech had only seventeen spaces. ${ }^{89}$ Undoubtedly, the state must provide funding for more spaces to accommodate more abused women and children. Importantly, these shelters need to be very close to or in the center of ultra-Orthodox and FLDS communities, facilitating easy access to those in need. The more isolated the community, the harder it is for the vulnerable to get help "because they're cut off from everything." 90 In addition to providing shelters for ultra-Orthodox and FLDS women and children, the state must create rehabilitation programs for abusers: men struggling with sexual abuse and domestic violence behavior.

Third, the state should require mandatory training about how to respond to domestic violence in any government-funded school. This requirement would empower individuals that live in extremist groups to know who to turn to for help if they are harmed or in fear of being harmed (as long as they attend a government-funded school).

These ideas, though simple are possible steps that the state might take to fulfill more fully its duty to protect individuals from religious extremism.

\section{Conclusion}

\footnotetext{
84 hillel.org.il/en/about.

${ }^{85}$ batmelech.org/who-we-are/about-us/.

86 thespectrum.com/story/news/2017/04/21/flds-women-forgotten-healing-inside-out/100700534/.

87 thespectrum.com/story/news/2017/04/21/flds-women-forgotten-healing-inside-out/100700534/.

88 batmelech.org/who-we-are/about-us/.

${ }^{89}$ batmelech.org/who-we-are/about-us/.

90 jpost.com/Magazine/Between-worlds-533476.
} 
State complicity in the face of religious extremism results in the abandonment of many vulnerable members of society. More than anything else, it is the hope this chapter will convince governments to act, for the public to demand protection for the vulnerable, and for the "at risk" to feel less isolated and abandoned. If there is a J'accuse in this essay, it is just that: State complicity in the face of extremism results in the abandonment of vulnerable members of society. The excuses, mantras, clichés, and "you have to understand" are old, weathered, and disingenuous. More importantly, they result in harm that-were the state not complicit-could be prevented. It is the failure to act-in the spirit of duty and obligation to vulnerable members of extremist groups-that enables their harm.

Why?

Because of state complicity.

It is as simple as that. 